\title{
A DESCONSTRUÇÃo DA ENCARNAÇÃO E DA RESSURREIÇÃO EM JEAN-LUC NANCY
}

\author{
The deconstruction of the incarnation and resurrection in Jean-Luc Nancy
}

Etienne Alfred Higuet *

Resumo: Pretendo, no presente artigo, aprofundar a visão da desconstrução do cristianismo em Jean-Luc Nancy, me concentrando na compreensão da encarnação e da ressurreição. Na primeira parte, procuro apresentar a fenomenologia do corpo e do tato, que sustenta a interpretação dos dogmas centrais do cristianismo: Os corpos são o limite, o espaço aberto, ou o lugar e o ser da existência. Na encarnação, o corpo é o evento do espírito, isto é, o espírito não se mantém fora do mundo, mas abre-se no meio dele. A desconstrução começa no apagamento de Deus no homem que é o sentido do mundo. Mas ela precisa se aprofundar como superação do corpo como signo do sentido enquanto interioridade, além de toda significação e representação. Por sua vez, a ressurreição desconstruída não visa a atravessar a morte, mas, ao mergulhar nela sem volta, a ressuscitar a própria morte. Nas considerações finais, procuro recapitular o que foi desconstruído, terminando com algumas reflexões sobre o futuro do cristianismo.

Palavras-chave: Cristianismo. Desconstrução. Corpo. Tato. Sentido. Morte.

Abstract: In this article, I intend to further Jean-Luc Nancy's vision of the deconstruction of Christianity, by focusing on the understanding of the incarnation and resurrection. In the first part, I try to present the phenomenology of the body and touch, which supports the interpretation of the central dogmas of Christianity: Bodies are the limit, the open space, or the place and being of existence. In the incarnation, the body is the event of the spirit, that is, the

\footnotetext{
* Graduado em filosofia e teologia. Doutor em Ciências teológicas e religiosas, pela Universidade Católica de Louvain, Bélgica. Professor aposentado do Programa de Pós-graduação em Ciências da Religião da Universidade Metodista de São Paulo. Última filiação na Universidade Federal de Juiz de Fora, MG. Artigo recebido em 30/11/2020 e aprovado para publicação em 02/12/2020.
} 
spirit does not remain out of the world, but opens itself in the midst of it. Deconstruction begins in the effacement of God in man, who is the sense of the world. However, deconstruction needs to further the overcoming of the body conceived as sign of a meaning understood as interiority, beyond all meaning and representation. In turn, the deconstructed resurrection does not involve going through death but, by plunging into it without return, resurrecting death. In the final considerations, I wish recap what has been deconstructed, ending with some reflections on the future of Christianity.

Keywords: Christianity. Deconstruction. Body. Touch. Sense. Death.

No início, já havia tudo. Mas Deus era cego e, perante tanto tudo, o que ele viu foi o Nada. Deus tocou a água e acreditou ter criado o oceano. Tocou o chão e pensou que a terra nascia sob os seus pés. E quando a si mesmo se tocou ele se achou o centro do Universo. E se julgou divino.

Estava criado o Homem.

Mia Couto

O que ouvimos, o que vimos com nossos olhos, o que contemplamos, e o que nossas mãos apalparam do Verbo da vida - porque a Vida manifestou-se: nós a vimos e lhes damos testemunho e vos anunciamos esta Vida eterna, que estava voltada para o Pai e que nos apareceu - o que vimos e ouvimos vo-lo anunciamos para que estejais também em comunhão conosco.

1Jo 1, 1b-3a

\section{Introdução}

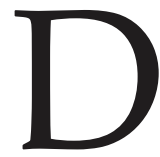
ediquei em 2013 e 2016 três artigos ao pensamento sobre a fé e a religião em Jean-Luc Nancy ${ }^{1}$, mais precisamente ao seu projeto de desconstrução do cristianismo. ${ }^{2}$ Mostrei como ele descobriu, no termo do processo de desconstrução, uma fé sem religião, isto é, sem crenças, sem ritos, sem instituições e até sem Deus, uma fé-práxis aberta

\footnotetext{
${ }^{1}$ Jean-Luc Nancy, filósofo francês, nasceu em Bordeaux em 1940. O meio cristão impregna seus anos de formação: a Juventude Católica, em primeiro lugar, e depois os ensinamentos do jesuíta Georges Morel, especialista de Hegel. Durante os estudos de filosofia na Sorbonne, é aluno de Georges Canguilhem e Paul Ricoeur e descobre Heidegger. Ao desistir de estudos de teologia, descobre o estruturalismo e encontra Jacques Derrida, Louis Althusser e Gilles Deleuze. Desde 1968, foi professor de filosofia na Universidade de Estrasburgo, onde se dedicou, junto com o colega e amigo Philippe Lacoue-Labarthe, a um trabalho de "desconstrução" das artes, especialmente da literatura, e do político, influenciado por Georges Bataille e Maurice Blanchot. A partir dos anos oitenta, volta às questões essenciais da filosofia, como finitude e infinito na existência humana. Com La déclosion (2005) e L'adoration (2010), o filósofo volta às fontes do cristianismo, para detectar a clausura que ainda precisa ser desconstruída, liberar todos os seus recursos para transcender o seu sentido, esgotar a sua essência. Agora aposentado, continua acompanhando a atualidade política e artística. Publicou recentemente reflexões sobre a situação mundial: Démocratie! Hic et nunc (com J.F. Bouthors) (2019) e La peau fragile du monde (2020).

${ }^{2}$ HIGUET, Etienne Alfred. A fé na filosofia pós-moderna: Jacques Derrida e Jean-Luc Nancy. Correlatio. Universidade Metodista de São Paulo, vol. 12, n 24, 2013, p. 29-48; HIGUET, Etienne
} 
à alteridade radical do infinito inapropriável, incognoscível, indizível, inominável do sentido. Num quarto texto, que deve estar disponível nos próximos dias como capítulo de livro, quis mostrar que, para Nancy, "a arte - como a fé - nos faz aceder ao limiar de um infinito intocável e inimitável, a uma força originária, a um presente de intensidade, a um fundo no qual ressoam as formas, a uma totalidade de sentido, a um imemorial aquém do nascimento e além da morte, a partir de um desejo antecipador de prazer." ${ }^{3}$

Para Nancy, o futuro da religião - especialmente do cristianismo - é a (auto) desconstrução. A esse respeito, nada melhor que citar o próprio filósofo:

Por "desconstrução do cristianismo", procuro designar o movimento que seria, ao mesmo tempo, uma análise do cristianismo - a partir de uma posição supostamente capaz de movê-lo para além de si mesmo - e o deslocamento, com mudanças, próprio ao cristianismo, pelo qual ele se move a si mesmo para além de si mesmo, na direção de recursos (aos quais ele dá acesso) que ele esconde e recupera de uma vez. Isso significa essencialmente o seguinte: o cristianismo não apenas se afasta do estritamente religioso, mas deixa marcado, além de si mesmo, o lugar em que deveremos finalmente abandonar a alternativa simplista do teísmo e do ateísmo. De fato, essa desconstrução está em obra, em várias modalidades, através do monoteísmo das "religiões do livro" no seu conjunto. Esse trabalho consiste sempre nisso, que o Deus "único" não é mais, precisamente, "um deus". ${ }^{4}$

Pretendo, no presente artigo, aprofundar a visão da desconstrução do cristianismo em Jean-Luc Nancy, me concentrando na compreensão da encarnação e da ressurreição, dedicando ao tema a segunda e a terceira parte do ensaio. Na primeira parte, procuro apresentar a fenomenologia do corpo e do tato, que sustenta a interpretação dos dogmas centrais do cristianismo. ${ }^{5}$ Nas considerações finais, tentarei recapitular o que foi desconstruído, terminando com algumas reflexões sobre o futuro do cristianismo.

Alfred. O projeto de desconstrução do cristianismo de Jean-Luc Nancy. Horizonte. PUCMG, Belo Horizonte, 2016a, vol. 14, p. 518-542; HIGUET, Etienne Alfred. A espiritualidade da adoração ( $A d-$ -oratio): reflexão a partir de Jean-Luc Nancy. Revista Brasileira de Filosofia da Religião. ABFR, Brasília, 2016b, vol. 3, no 1, p. 92-111.

${ }^{3}$ HIGUET, Etienne Alfred. Leitura filosófica da pintura cristã. In: CALVANI, Carlos E. B.; BEZERRA, Cícero C. (Org.). Religião: linguagens. Curitiba: Editora CRV, 2020, p. 177-192.

${ }^{4}$ NANCY, Jean-Luc. Noli me tangere. On the Raising of the Body. New York: Fordham University Press, 2008, p. 108, nota 4.

${ }^{5}$ No livro que ele dedicou a Jean-Luc Nancy, Jacques Derrida entende que a questão do tato ou do tocar é "o melhor fio diretor, o mais econômico, para re-começar a ler Nancy aujourd'hui, de modo ao mesmo tempo diacrónico e sincrónico." Ver: DERRIDA, Jacques. Le toucher, Jean-Luc Nancy. Paris : Galilée, 2000. Não foi possível incluir neste breve ensaio a longa conversa que Jacques Derrida mantém neste livro, não apenas com Nancy, mas com toda a tradição filosófica do tato. 


\section{Hoc est enim corpus meum: Fenomenologia do corpo e do tato/tocar}

\subsection{Corpo de Deus - corpo do homem}

Hoc est enim corpus meum (isto é o meu corpo) é uma fórmula universal em todas as religiões. No cristianismo, ela indica a presença real ou simbólica do corpo de Deus. Vivemos na angústia e no desejo de ver, tocar e comer o corpo de Deus, de ser este corpo que, na realidade, não se pode ver, nem tocar, nem aqui nem em outro lugar. Pois é a presença do Ausente por excelência.

A partir da "morte de Deus" (que Jean-Luc Nancy considera uma base irreversível da nossa (pós)modernidade), o que aconteceu com o corpo de Deus? Na verdade, não havia corpo de Deus. O corpo de Deus era o corpo do próprio homem: a carne do homem era o corpo que Deus se tinha dado. "Deus se tinha feito corpo, se tinha estendido e amassado ex limon terrae" , como lemos no livro de Gênese. Por isso, "os corpos são a exposição de Deus, e não há nenhuma outra - se é que Deus se expõe". Temos então, de um lado o corpo divino putrefato e petrificado, e do outro lado, como a outra parte da mesma morte de Deus, o corpo divino exposto, primeira manifestação material do mundo dos corpos, transformação radical de Deus. "Isto é: nenhum Deus, nem mesmo os deuses, apenas os lugares". ${ }^{8} \mathrm{O}$ "divino" colapsa e se retira, deixando desnudo o mundo dos nossos corpos: lugares do desnudamento, do limon terrae. Pois, um mesmo gesto levanta Deus como corpo da morte, e entrega o espaço à multiplicação dos corpos.

Com o corpo, que ele se dá, do homem ou da mulher, o criador não reproduz a sua imagem. Seu poder consiste na desconstrução originária de toda imagem reconhecível. O mundo criado não imita nada. O corpo é a imagem - mas enquanto é a visibilidade do invisível. O corpo é a "vinda à presença", como a imagem que vem à tela da televisão, do cinema, não vindo de nenhum fundo da tela, sendo o espaçamento desta tela. A própria vinda não acaba de vir, "ritmo ou glória dos corpos que nascem, que morrem, que se abrem, que se fecham, que gozam, que sofrem, que se tocam e se afastam". ${ }^{9}$ Então, chegou o tempo de escrever e pensar este corpo no distanciamento infinito que o faz nosso, que o faz vir de mais longe que todos os nossos pensamentos: o corpo exposto da população do mundo.

\footnotetext{
${ }^{6}$ NANCY, Jean-Luc. Corpus. Paris: Métaillé, 2000a, p. 55.

${ }^{7}$ NANCY, Jean-Luc. Corpus. Paris: Métaillé, 2000a, p. 55.

${ }^{8}$ NANCY, Jean-Luc. Corpus. Paris: Métaillé, 2000a, p. 57.

${ }^{9}$ NANCY, Jean-Luc. Corpus. Paris: Métaillé, 2000a, p. 57.
} 


\subsection{Exposição e distanciamento}

O que pensar desse ser-lançado-aí que o corpo é? Pensar os corpos é "pensamento que toca à dura estranheza, à exterioridade não-pensante e não-pensável deste corpo. Os corpos não têm lugar, nem no discurso, nem na matéria. Eles acontecem no limite, enquanto o limite" ${ }^{10}$ Os corpos não são espaço preenchido, são o espaço aberto, ou o lugar. Os corpos são lugares de existência, sem os quais não há existência. Como pele, o corpo dá lugar à existência, a qual não possui essência. O corpo é o ser da existência. O corpo, ou os corpos, que se trata de tocar pelo pensamento, são extensão e exterioridade da presença-ao-mundo.

Na vida toda, o corpo é também um corpo morto, o corpo de um morto, desse morto que sou, mesmo sendo vivo. Pois

os corpos estão sempre em partida, na iminência de um movimento, de uma queda, de um distanciamento, de uma deslocação. [...] O corpo que parte leva consigo o seu espaçamento, se leva a si mesmo como espaçamento e, de algum modo, se coloca à parte, se esconde atrás de si mesmo. Mas, ao mesmo tempo, ele deixa esse mesmo espaçamento "atrás dele", isto é, no seu lugar, e esse lugar continua o seu, absolutamente intato e absolutamente abandonado, ao mesmo tempo. ${ }^{11}$

Esse espaçamento, essa partida, é sua própria intimidade. A exposição é o próprio ser, o existir, e o corpo é o ser-exposto do ser. Não há sentido em falar em corpo e em pensamento separadamente, como se eles pudessem ter alguma subsistência cada um por si: cada um, corpo e pensamento, é apenas toque no outro, o toque da sua efração do outro. Esse toque é o limite, o espaçamento da existência. Contudo, ele tem nome, chama-se "alegria", "dor" ou "pena", ou ainda, "sexo".

“O nosso mundo é o mundo dos corpos, porque ele é a densidade mesma do espaçamento, ou a densidade, e a intensidade, do lugar. [...] É o mundo da apropriação do próprio: mundo da não-generalidade, mundo não oferecido à 'humanidade', mas a seus corpos singulares", ${ }^{12}$ mundialmente. No gesto, no endereçamento, no espaçamento, os corpos (como, por exemplo, os corpos dos amantes) não se entregam à transubstanciação, eles se tocam, eles renovam constantemente o seu espaçamento, se afastam, se dirigem um ao outro.

E o meu corpo? O meu corpo nunca é propriamente "eu", pois é sempre ob-jetado de fora, a "mim" ou a outrem. É a partir do meu corpo que sou endereçado ao meu corpo. "É desde o meu corpo que tenho o meu corpo

\footnotetext{
${ }^{10}$ NANCY, Jean-Luc. Corpus. Op. Cit., p. 18.

${ }^{11}$ NANCY, Jean-Luc. Corpus. Op. Cit, p. 31-32.

${ }^{12}$ NANCY, Jean-Luc. Corpus. Op. Cit., p. 37-38.
} 
como alheio a mim mesmo, expropriado" ${ }^{13}$ Pois os corpos, inclusive o meu, são em primeiro lugar e sempre outros - do mesmo modo que os outros são em primeiro lugar e sempre corpos. A alteridade consiste sempre na singularidade de um corpo. Mas o mundo ao qual eu nasço, morro, existo, não é só o mundo "dos outros", já que é tanto "meu" quanto dos outros.

\subsection{Corpo tocado ${ }^{14}$}

"Sentido: o distanciamento de um tato."15 Antes de tudo, o corpo é peso. Todos os corpos pesam uns sobre os outros e uns contra os outros. Os corpos pesam levemente, pois o seu peso é a elevação de suas massas à superfície. Sua interioridade se expõe na extensão, não na concentração (a concentração, KZ, é a aniquilação dos $\operatorname{corpos}^{16}$ ). É a ordem da vinda. Os corpos vêm pesar uns contra os outros, eis o mundo. Os corpos exercem a sua pesada recíproca em todo o espaçamento do mundo. "É isso mesmo, o "sentido", o ser-sem-origem e o vir-a-ser-estendido, o ser-criado, ou a pesada." ${ }^{17}$ A extensão (ser-estendido) é o lugar das pesagens, o lugar da diferenciação, e, por conseguinte, da comunidade do mundo. Todos os corpos (não só os corpos humanos, mas também as pedras e as lagartixas, por exemplo), uns fora dos outros, constituem o corpo inorgânico do sentido. De certo modo, são mundo como extensão de área, espaçamento, distância, constituição "atomística". É pelo distanciamento entre singularidades que, primeiramente, há mundo.

Nancy chama de alma o fato de que um corpo existe, isto é, que há extensão e ex-posição. "O corpo é então oferecido, apresentado aberto para fora. Um corpo toca no exterior, mas, ao mesmo tempo, ele se toca como

\footnotetext{
${ }^{13}$ NANCY, Jean-Luc. Corpus. Op. Cit. p. 19

${ }^{14}$ Jean-Luc Nancy usa todas as conotações de tato, tocar, toque. Pode ser simplesmente "tocar" ou "tratar, abordar, considerar (toucher à)", ou ainda "comover, chocar". Há também os substantivos le toucher e la touche, e o verbo reflexivo se toucher (tocar a si mesmo ou tocar uns aos outros, com possível significado sexual). A maior parte das conotações do francês está presente também no português "tocar", conforme o dicionário de Aurélio: pôr a mão em, tocar em, palpar; ter contato com; atingir com um golpe, na esgrima; comover, sensibilizar, abalar, impressionar; agitar, excitar; referir-se a, mencionar, citar; dizer respeito, pertencer, interessar; ter contato, passar de leve. O substantivo remete ao sentido do tato, de novo com múltiplas conotações. Nancy estabelece uma lista não exaustiva dos verbos que se relacionam com o tato: "encostar, apertar, enfiar, alisar, coçar, acariciar, apalpar, massagear, abraçar, bater, beliscar, morder, chupar, molhar, segurar, soltar, lamber, masturbar, olhar, escutar, experimentar, evitar, transar, ninar, balançar, carregar, pesar.." ("effleurer, frôler, presser, enfoncer, serrer, lisser, gratter, frotter, caresser, palper, tâter, pétrir, masser, enlacer, étreindre, frapper, pincer, mordre, sucer, mouiller, tenir, lâcher, lécher, branler, regarder, écouter, flairer, goûter, éviter, baiser, bercer, balancer, porter, peser..."). (Corpus, p. 82).

${ }^{15}$ NANCY, Jean-Luc. Le sens du monde. Paris: Bayard, 1993, p. 104.

${ }^{16}$ Referência aos campos de concentração dos regimes totalitárias, especialmente nazista: KZ, Konzentrationslager.

${ }^{17}$ NANCY, Jean-Luc. Corpus. Paris: Métaillé, $2000^{\mathrm{a}}$, p. 83.
} 
exterior." ${ }^{18}$ É pela minha pele que eu me toco. E toco-me de fora, não de dentro. A pele não é outra coisa senão o limite no qual um corpo toma sua forma. A pele anima o corpo, não o envelopa como num saco, mas o dirige ao mundo e a ele mesmo. A pele não cobre, ela forma, molda, expõe e anima este conjunto incrivelmente complexo, que é o corpo. "É preciso insistir na simbiose de um corpo com o exterior, que é apenas a contiguidade dos outros corpos, desde o ar até as estrelas, passando pelos cardos, as teclas (touches) do teclado e a mão do vizinho..."19

“O espírito e o corpo são as duas faces de uma mesma realidade ativa ou, se preferir, de uma mesma atividade real. A pele representa e apresenta muito bem - mas a pele toda, tudo o que faz pele, toda infinita superfície móvel formando e se deixando formar - a conjunção do espírito e do corpo." ${ }^{20}$ Isso se aplica aos gestos do corpo inspirado do artista. É nessa sensualidade espiritual que se experimenta que há mundo, mundos, fazer-desfazer-dos-mundos.

"Eu" não é outra coisa senão a singularidade de um toque, de um toque enquanto um toque é sempre ao mesmo tempo ativo e passivo e que um toque evoca algo pontual. "A unidade de um corpo, a sua singularidade, é a unidade de um toque, de todos os toques (de todos os tocares) desse corpo. E é essa unidade que pode fazer um eu, uma identidade. Não uma interioridade, mas uma singularidade." ${ }^{21}$ Um sujeito como ser fora de si, como "se sentir", como sentir uma existência. É a própria existência que se sente como existência. Só há um "se sentir" como relação a si como fora. O ser si é necessariamente ser fora, de fora, ser exposto ou estendido (como o Dasein de Heidegger). Nem prisão da alma, nem expressão de uma interioridade, o corpo é extensão, espaçamento, separação, síncope tensa entre um grito de nascimento e um suspiro de morte, que junta o corpo a ele mesmo e os corpos entre si. Síncope de aparecimento e desaparecimento, de enunciação e de sentido, também síncope de desejo.

Como "eu", que não teria nenhum lugar, viria em um lugar? É o mistério da encarnação. Mas, justamente, não podemos de modo algum pensar o corpo em termos de encarnação. A encarnação é o modelo (cristão) de todo o nosso pensamento do sujeito. Ora, essa ideia da encarnação é impossível. Precisamos pensar, não num sem-lugar que viria ocupar um lugar, mas num "ser aí" (Heidegger), feito de abertura e de exposição.

\footnotetext{
${ }^{18}$ NANCY, Jean-Luc. Corpus. Op. Cit., p. 117.

${ }^{19}$ NANCY, Jean-Luc e LĖBRE, Jérôme. Signaux sensibles. Entretien à propos des arts. Paris: Bayard, 2017, p. 66.

${ }^{20}$ NANCY, Jean-Luc e LÈBRE, Jérôme. Signaux sensibles. Op. Cit., p.66.

${ }^{21}$ NANCY, Jean-Luc. Corpus. Op. cit., p. 122.
} 


\section{Desconstrução da encarnação}

Verbum caro factum est (o verbo foi feito carne) ou logos sarx egéneto (o logos tornou-se carne), no prólogo do Evangelho de João, é a fórmula da "encarnação", pela qual Deus se faz homem.

O cânon estrito da fé católica define que em Cristo "As duas naturezas não são apenas unidas por homonímia, nem por graça, nem por relação, nem por confusão, nem pela única nomeação ou adoração, nem pela conversão de uma natureza na outra, mas conforma a subsistência (hypostasis)". Só há uma hipóstase para as duas naturezas do homem e do deus. Não há nem fusão, nem distinção: mas há um lugar único de subsistência e de presença, um lugar no qual o deus aparece inteiramente no homem, e o homem aparece inteiramente em deus. Não há lá nem divinização do homem, nem humanização de Deus. Mas há: como o homem aparece ao deus, no deus, como o deus aparece ao homem, no homem, e como isso mesmo é totalmente inaparente. ${ }^{22}$

A humanidade de Deus é, ao mesmo tempo, o traço decisivo do cristianismo e um traço determinante de toda a cultura ocidental, até no coração do seu "humanismo". A expressão significa que o verbo não precisou penetrar numa carne antes dada fora dele: o próprio verbo tornou-se a carne. A encarnação não é a morada provisória do deus na carne, é o "verbo feito carne", ou a própria carne como sentido. O corpo cristão não é envelope, prisão ou túmulo da alma. Ele é o próprio logos que se faz corpo enquanto logos. É o corpo como imagem visível do invisível, manifestação do que não se manifesta. Esse corpo é o "espírito" saído de si mesmo ou de sua pura identidade para se identificar, não ao homem, mas como o homem (e a mulher, e a matéria).

Pois o corpo é o evento do espírito, isto é, o espírito não se mantém fora do mundo, mas abre-se no meio dele..$^{23}$

Com a figura de Cristo, a renúncia ao poder divino e à sua presença torna-se o próprio ato de Deus. O "deus" se fez "corpo" ao esvaziar-se de si mesmo (kénosis), e o "corpo" torna-se o nome do a-teu no sentido de "nenhum-deus", o que não significa a autossuficiência imediata do homem e do mundo, mas, nenhuma presença fundante. A ausência ou o vazio-de-divindade á a sua verdade mais profunda. Em Jesus, Deus não apenas se ausenta, mas se apaga. Além disso, ele se faz homem, abandona a sua divindade à condição mortal, em vista de revelar a imortalidade na morte. Ao adotar o caráter mortal da carne humana, ele abre na morte uma outra vida, uma vida eterna. E o homem no qual Deus "desce" e "se esvazia"

\footnotetext{
${ }^{22}$ NANCY, Jean-Luc. Des lieux divins, suivi de Calcul du poète. 2. ed. Mauvezin (França): T.E.R., 1997, p. 36-37.

${ }^{23}$ Cf. NANCY, Jean-Luc. L'adoration (Déconstruction du christianisme II). Paris: Galilée, 2010, p. 74-78.
} 
não é divinizado. Deus permanece apenas como traço, vestígio impalpável, imperceptível. O apagamento de Deus no homem é o sentido do mundo. ${ }^{24}$ Enfim, há uma última intensificação da encarnação na "transubstanciação" do corpo do Cristo em pão e vinho de uma "comunhão" , pois seu corpo divino não se converte apenas em corpo humano, mas também em matéria inorgânica, fazendo assim investir por "deus" uma realidade - pão e vinho - oriunda de uma transformação da natureza pela técnica humana. ${ }^{25}$

Por outro lado, há motivos sérios para justificar a desconstrução da compreensão cristã da encarnação. É que o corpo da encarnação é signo, do começo ao fim. "É o signo do sentido, isto é, não a vinda do sentido, mas uma remissão ao sentido como interioridade, como "dentro". [...] É a significação (ou a representação) que dá sentido ao corpo, fazendo dele mesmo signo do sentido, corpo significante" ${ }^{26}$ Todos os corpos são signos, pois todo corpo é estruturado para remeter ao sentido. O corpo significante não para de se construir, e ele é por excelência instância de contradição: ou porque é por ele que há significação (por exemplo, corporeidade da linguagem) ou porque ele constitui obstáculo ao sentido.

Na encarnação, é o espírito que é o órgão do sentido, ou o verdadeiro corpo, o corpo transfigurado. Ao se fazer carne, o espírito se revela a si mesmo, ele profere a respeito da sua carne: hoc est enim corpus meum, ele se articula a si mesmo com toda presença sensível. Então, o que a encarnação revela "é o corpo como mistério revelado, o signo absoluto de si e a essência do sentido, o Deus retirado na carne, a carne subjetivada a si mesma, o que se nomeia, enfim, no pleno esplendor do Mistério, a 'ressurreição'". ${ }^{27}$

Assim, o espírito do cristianismo, isto é, o cristianismo enquanto teologia do Espírito Santo, está aqui por inteiro. "O filho é o corpo, não a expansão criadora dos corpos, mas o corpo do espírito, reunido, concentrado sobre o seu sopro, oferecido em sacrifício ao pai, ao qual ele se junta novamente ao expirar, corpo do último grito, do último suspiro no qual tudo é consumado. Pater, hoc est enim corpus meum: spiritus enim sanctus tuus." 28 Ao se exalar face ao Pai, o filho como corpo do Espírito expõe do modo mais próprio seu próprio corpo: Ecce homo. O que faz verdadeiramente o corpo (do) espírito é uma chaga, um corpo que passou nas suas chagas. É também desse modo que se anuncia a mundialização dos corpos, chagas amontoadas das vítimas nas quais o corpo perde sua forma e seu sentido - e o sentido perdeu todo corpo.

\footnotetext{
${ }^{24}$ Cf. HIGUET, Etienne Alfred. O projeto de desconstrução do cristianismo de Jean-Luc Nancy. Horizonte. PUCMG, Belo Horizonte, 2016a, vol. 14, p. 528.

${ }^{25}$ Cf. NANCY, Jean-Luc. La déclosion (Déconstruction du christianisme I). Paris: Galilée, 2005, p. 126.

${ }^{26}$ NANCY, Jean-Luc. Corpus. Op. cit., p. 60.

${ }^{27}$ NANCY, Jean-Luc. Corpus. Op. cit., p. 77.

${ }^{28}$ NANCY, Jean-Luc. Corpus. Op. cit., p. 68.
} 
Para responder à mundialização, será necessária uma nova criação dos corpos, não através da encarnação, que insuflaria neles a vida espiritual do signo, mas pela colocação no mundo e a partilha dos corpos. ${ }^{29}$ Trata-se da criação como écotechnie dos corpos, conectando os corpos de todos os modos, os colocando nos lugares de interseções, de interfaces, de interações de todos os procedimentos ecotécnicos. Não precisamos de corpos produzidos pela autoprodução do espírito e sua reprodução, mas de corpos criados pela techné (no sentido aristotélico de arte) dos corpos. O nosso mundo é o mundo das "técnicas" ou, melhor, de uma "ecotécnica", que produz os nossos corpos pela conexão aos aparelhos técnicos. ${ }^{30}$ É aqui que está a verdade do nosso mundo, não mais nos mitos, nas religiões e nos humanismos.

Isto é, este mundo pede o corpo de um sentido que não forneça a significação do corpo, ainda menos o reduza a ser seu próprio signo e a essência acabada de todas as ontoteologias do signo. O mundo novo pede o inverso da encarnação, a qual monopolizava no mundo antigo todas as modelizações, todos os espaçamentos do corpo. Para criar o mundo dos corpos, a "ecotécnica" substitui as projeções de histórias lineares de fins últimos por espaçamento de tempo. Ela desconstrói assim o sistema dos fins, tornando o mundo dos corpos capaz de resistir ao império da economia política e do capital. ${ }^{31}$

\section{Desconstrução da ressurreição}

\subsection{Ressurreição de Blanchot}

Jean-Luc Nancy desconstrói a compreensão cristã da ressurreição ao comentar textos de Maurice Blanchot. ${ }^{32}$ Para Blanchot, a ressurreição não

\footnotetext{
${ }^{29}$ É por isso que Jean-Luc Nancy acaba privilegiando o conceito de "corpo" em relação com o de "carne", que é sempre entendido como carne animado por um elemento espiritual. Michel Henry adota a intenção inversa, no seu livro Incarnation. Une philosophie de la chair. Paris: Seuil, 2000. Dediquei recentemente um ensaio à fenomenologia da carne de Michel Henry. Faltaria estabelecer uma discussão entre os dois filósofos fenomenólogos. Ver: HIGUET, Etienne Alfred. Vida e Encarnação no ser humano, em Cristo e na pintura de Kandinsky. Leitura de Michel Henry. Estudos de Religião, v. 34, n.2, maio-ago. 2020, p. 41-69.

${ }^{30}$ Jean-Luc Nancy conta, num pequeno livro muito "tocante", a história do transplante de coração que salvou sua vida. Ele saúda assim um feito da ecotécnica, a vinda da prótese no coração do corpo próprio. Posso dar o testemunho pessoal de que, alguns anos atrás, uma prótese salvou a minha perna de uma fratura aberta. Ver: NANCY, Jean-Luc. L'intrus. Paris: Galilée, 2000b; ANTONIOLI, Manola. O tocar - Jacques Derrida e Jean-Luc Nancy. In: EYBEN, Piero (Org.). Pensamento intruso. Jean-Luc Nancy \& Jacques Derrida. Vinhedo, SP : Horizonte, 2014, p. 33.

${ }^{31}$ Ver: NANCY, Jean-Luc. Corpus. Op. Cit., p. 73-79.

${ }^{32}$ Résurrection de Blanchot, em NANCY, Jean-Luc. La déclosion (Déconstruction du christianisme I). Paris: Galilée, 2005, p. 135-146.
} 
consiste em ressuscitar os mortos, em devolvê-los à vida milagrosamente, mas constitui, ao contrário, a extremidade e a verdade do morrer. Ela não visa a atravessar a morte, mas, ao mergulhar nela sem volta, a ressuscitar a própria morte.

O protagonista do romance Thomas l'obscur (1941) remete explicitamente ao Lázaro do Evangelho de João. O narrador diz dele: "Ele andava, único Lázaro verdadeiro cuja própria morte era ressuscitada." E ainda: "[...] ele aparecia na porta estreita do seu sepulcro, não ressuscitado, mas morto e tendo a certeza de ser arrancado ao mesmo tempo da morte e da vida". ${ }^{33}$ “Ele não está ressuscitado, isto é, não reencontra a vida depois de atravessar a morte, mas, ficando morto, ele anda na morte e é a própria morte que é ressuscitada neste 'único verdadeiro Lázaro'." ${ }^{34}$ Como Cristo, Thomas é a Ressurreição. A ressurreição não é uma segunda vida, mas é o endireitamento pelo qual o curso horizontal de uma vida gira em sentido vertical.

Para Blanchot, a ressureição designa o acesso ao além do sentido, por meio de um passo que não vai a lugar nenhum, a não ser à sua própria repetição. "O espaço da ressurreição, que a define e a torna possível, é o espaço fora do sentido que antecede o sentido e lhe sucede, num fora-do-tempo (hors-temps) tão interminável quanto instantâneo, a eternidade no seu valor essencial de subtração." 35 Sua vida, afastada do sentido, não ressuscita como vida, mas ressuscita a própria morte: no lugar do evento da morte, que é o falecimento da mortalidade, ela coloca o morrer da imortalidade.

Podemos perceber, nessa transformação do fato da morte, a retração radical do sentido que é a própria verdade e a nossa libertação. A morte não me chega mais como um corte que se impõe a mim em particular, mas se torna o destino comum e anónimo que ela só pode ser. Na morte ressuscitada, na qual me ausento de mim mesmo e do sentido, não me exponho apenas à verdade, mas sou eu mesmo a verdade em ato. A presença opaca da pedra do sepulcro é a verdade da transparência esperada, e a obscuridade de Thomas é a clareza verdadeira. Graças à escrita, tornando pública sua morte em ação, a vida de Blanchot foi uma vida ressuscitada. Ao viver sua vida como já morta, ele a transformou em ressurreição.

Por outro lado, a ressurreição aparece como reescrita da Sagrada Escritura, enquanto "consentimento", correspondência à própria realidade do morrer, "paciência da passividade", pela qual é dado de "responder ao impossível e do impossível". ${ }^{36}$ Não se trata de submissão nem de resignação, mas de encontrar um sentido ou um sentir: o sentir do insensível e a ausência do sentido. É a experiência infinitamente simples e indefinidamente renovada

${ }^{33}$ NANCY, Jean-Luc. La déclosion. Op. cit., p. 137.

${ }^{34}$ NANCY, Jean-Luc. La déclosion. Op. cit., p. 138.

${ }^{35}$ NANCY, Jean-Luc. La déclosion. Op. cit., p. 40-41.

36 NANCY, Jean-Luc. La déclosion. Op. cit., p. 145. 
de ser sem essência e, assim, de morrer. ${ }^{37} \mathrm{O}$ consentimento à ressurreição consente, antes de tudo, à recusa da crença, assim como a fé recusa e exclui essa mesma crença. Na realidade, a crença nunca é crível, nós o sabemos desde sempre: "foi sempre o pressentimento do absolutamente inacreditável, desafiando sem apelo qualquer credulidade e se confiando, absolutamente, que nos proporcionou a via sem saída do consentimento." ${ }^{38}$

\subsection{Consolação, desolação: a ressurreição de Derrida}

Num outro texto, Nancy responde a Derrida, para quem o fim do mundo - que acontece em cada morte - é o fim de toda ressurreição. É preciso rejeitar até "a anastasis da qual fala Jean-Luc Nancy", pois continua consolando: Ela postula a existência de algum Deus e que o fim de um mundo não seria o fim do mundo. ${ }^{39}$ De fato, ao morrer, o morto carrega com ele o seu mundo, que era só dele ou que era ele mesmo. Ao levar o seu mundo, ele leva efetivamente o mundo inteiro, pois todo mundo é singular. Só se pode dar um "salve" (saudar/salvar) (salut) ao mundo solitário ou isolado que ficou "desolado" (désolé), sem consolo, pois não se pode reencontrar a presença e a vida daqueles que estão mortos. Todo consolo só poderá reforçar a desolação. “O que a morte nos oferece é tocar ao intato, e isso significa que o morto desaparece no isolamento absoluto da sua morte intocável." ${ }^{40}$ Saudando o nome dele a partir da borda de cá, estou também absolutamente só frente ao isolamento dele.

Contudo, o "salve" [salut] continua saudando e convocando o morto pelo nome, dando a totalidade de sentido ao nome agora privado de sentido. Ele consola e se consola, pela voz do seu "salve" ao que não se deixa saudar/salvar. Esse "salve" não salva nada do abismo, mas saúda o abismo salvo. O abismo impossível de ser fechado ou sondado dá ao "salve" a dignidade do mundo em colapso. Ao mesmo tempo, o "salve" dá ao mundo abismado (abîmé) sua dignidade de mundo. ${ }^{41}$

Na desconstrução do seu significado de "ressurreição", a anastasis ${ }^{42}$ só traz à tona o endireitamento, o erguimento do sentido abismado em verdade

\footnotetext{
${ }^{37}$ NANCY, Jean-Luc. La déclosion. Op. cit., p. 145.

${ }^{38}$ NANCY, Jean-Luc. La déclosion. Op. cit., p. 146.

${ }^{39}$ NANCY, Jean-Luc. La déclosion. Op. cit., p. 148.

${ }^{40}$ NANCY, Jean-Luc. La déclosion. Op. cit., p. 149.

${ }^{41}$ Jacques Derrida introduz assim o seu livro sobre Nancy: "Quis esboçar um primeiro movimento para saudar alguém, o saudar, ele, Jean-Luc Nancy. Alguém que escreve hoje como ninguém. E para saudá-lo assim sem faltar ao tato - o tocar sem o tocar - arrisquei o gesto sempre elíptico do "salve", de fato um apelo contido, inacabado, inibido. Tímido. Que não procura demasiadamente aproximar-se, impor-se, menos ainda apropriar-se".

${ }^{42}$ Em grego, anastasis tem os seguintes significados: ação de elevar, erguer; ação de derrubar completamente, destruição, ruina; ação de se levantar (após o sono); ação de se levantar, se insurgir; ação de se reerguer após uma queda; ressurreição no sentido cristão; ação de se afastar, de sair. Ver: BAILLY, Anatole. Dictionnaire Grec-Français. Paris: Librairie Hachette, 1950, p. 140.
} 
anunciada e saudada. A verdade só pode ser saudada, nunca salva, pois não há nada a salvar da profundeza do desfalecimento: mas até isso se saúda, na oração fúnebre, que pertence ao evento do "morrer". Saúda-se o morrer próprio daquele ou daquela que foi aqui ou lá (que foi o mundo aqui ou lá) e não é mais nem será em nenhum lugar e em nenhum tempo. Apesar do seu jazer, o morto endireita-se como verdade saudada. Na realidade, até para as religiões, o túmulo não é uma passagem, é um não-lugar que abriga uma ausência. A fé nunca consiste numa crença na felicidade futura. Ela é saudação (salut) ou endereçamento ao outro do mundo, pois "Deus" não designa senão esta alteridade na qual a alteração do mundo, de todo o mundo, se faz absoluta, sem recurso possível.

Tanto o sujeito que morre, quanto aquele que, saudando-o, se endereça a ele no lugar no qual nenhum endereçamento chega, saúdam-se sem se salvar. Partilham a anastasis, cuja elevação ou retidão corta na perpendicular o jazer sem volta do corpo na poeira. Não há qualquer sobrevida, qualquer ressurgência, qualquer revivescência. Mas "ressurreição" no sentido de elevação da saudação [salut], do adeus: a partida é o seu próprio anúncio, que não revela nada. Cada vez, a oração sem espera e sem efeito constitui a anastasis do discurso, a saudação se ergue e se endereça ao ponto exato onde nada mais resta a dizer. [...]

Sem nos salvar, uma tal saudação [salut], pelo menos, nos toca e, tocando-nos, suscita em nós esta estranha perturbação de atravessar a vida para nada - mas não exatamente em pura perda. ${ }^{43}$

\subsection{Noli me tangere: a ressurreição para Maria de Magdala}

No texto intitulado Noli me tangere - Essai sur la levée du corps ${ }^{44}$, Jean-Luc Nancy desconstrói a leitura cristã da narrativa de Jo 20, 13-18. Num prólogo, o autor situa o gênero literário do texto: trata-se de uma parábola. "Ele falava em parábolas". Se a parábola constitui um modo de figuração por meio de uma estória representando um conteúdo moral, a vida inteira de Jesus é a representação da verdade que ele mesmo reivindica ser. Esta vida é a verdade que se apresenta ao ser representada. Do mesmo modo, a fé cristã se volta para a apresentação efetiva da verdade numa vida ou existência singular, e não apenas para as palavras ou ensinamentos de um profeta. Nesse sentido, a própria fé é parabólica: o logos não

\footnotetext{
${ }^{43}$ NANCY, Jean-Luc. La déclosion. Op. cit., p. 152-153.

44 "Não me toque" (tradução da Vulgata) - Ensaio sobre a elevação/levantamento/remoção (ao mesmo tempo levantar o corpo do chão e levar o corpo à igreja, ao cemitério, como parte da cerimônia do funeral). Infelizmente, só tive acesso à tradução inglesa. Contudo, os tradutores tiveram a feliz ideia de colocar as palavras francesas entre parênteses quando havia dificuldade de tradução. Em particular, houve a necessidade de usar várias palavras para traduzir as diversas conotações do verbo e substantivo toucher.
} 
se distingue da figura ou da imagem pela qual ele se apresenta. Não há verdades secretas ou misteriosas para serem desvendadas. Na perspectiva da "desconstrução do cristianismo", a "revelação" constitui a identidade do revelável e do revelado, do "divino" e do "humano" ou do "mundano". Para a revelação, a imagem é idêntica ao original, o que implica a identidade do invisível e do visível.

O primeiro objetivo da parábola, conforme as afirmações paradoxais de Jesus (Mt 13,11-16), é confirmar a cegueira daqueles que não veem, não usar uma pedagogia da alegoria ou da ilustração. Para receber a revelação, é preciso ter uma disposição ou sensibilidade receptiva, a qual, por sua vez, precisa ter sido recebida. As parábolas cristãs trazem uma advertência: "se você não entende, não procura o motivo na obscuridade do texto, mas apenas dentro de você mesmo, na obscuridade do seu coração." ${ }^{45}$ Para o olho aberto, a mensagem é sempre a aparição repentina de um sentido ou de um além-do-sentido: de um eco singular no qual me ouço a mim mesmo me dirigindo a mim mesmo e respondendo a mim mesmo na voz do outro. Trata-se da fé, que se deixa interpelar por um chamado desconcertante através do outro, sendo lançada à escuta do desconhecido.

\subsection{Partida (en partance)}

Jean-Luc Nancy encontra um exemplo desse aparecimento/desaparecimento repentino no episódio do evangelho de João conhecido como Noli me tangere. Nessa cena, que faz parte da grande parábola da vida e missão de Jesus, Jesus fala, faz um apelo e parte. Ele quer dizer que está em iminência de partida, que, ao mesmo tempo que está aqui, já está em outro lugar. Cabe ao outro compreender, ver e ouvir. Esse episódio foi representado inúmeras vezes na pintura, usando geralmente como título a expressão da Vulgata que traduz o grego mè mou haptou: "Noli me tangere/Não me toque". A expressão evoca uma proibição de contato, por uma questão de sensualidade ou violência, um recuo, uma fuga por medo ou pudor, mas nada que possa indicar um caráter religioso ou sagrado. $\mathrm{O}$ evangelho deve ter retomado a expressão da linguagem comum, no sentido de um aviso de perigo, de ferir ou ser ferido, de precisar se defender para preservar a própria integridade. A frase fala do tocar em geral, ou ela toca no ponto sensível do tocar, o ponto no qual o tocar não toca, ou toca sem tocar: "o ponto do espaço sem dimensão que separa o que o tocar junta, a linha que separa o tocar do tocado e, assim, o toque de si mesmo." ${ }^{46}$

\footnotetext{
${ }^{45}$ NANCY, Jean-Luc. Noli me tangere. On the Raising of the Body. New York: Fordham University Press, 2008, p. 9.

${ }^{46}$ NANCY, Jean-Luc. Noli me tangere. On the Raising of the Body. New York: Fordham University Press, 2008, p. 13
} 
A arte e a cultura destacaram essa frase em vista de resgatar algo que o cristianismo procurava excluir de si mesmo, o tabu como estrutura constitutiva da sacralidade. O intocável está sempre presente onde há sagrado e, em consequência, retraimento, distância, distinção, e o incomensurável, com toda a emoção que o acompanha. Mas, em certo sentido, nada nem ninguém são intocáveis no cristianismo, já que até o corpo de Deus é dado de comer e beber (apesar de alguns retrocessos no catolicismo e na ortodoxia). Em certo sentido, o cristianismo foi a invenção da religião do toque, do sensível, da presença imediata ao corpo e ao coração. A cena do Noli me tangere seria uma exceção? Ou as frases Hoc est corpus meum e Noli me tangere deveriam ser tomadas juntas, como uma espécie de oxímoro ou paradoxo. Em nenhum outro momento Jesus se recusou a ser tocado, a não ser neste momento no qual se trata do seu corpo ressuscitado. $O$ texto mostra claramente que não se trata de um corpo espectral ou fantasmagórico, mas de um corpo tangível. Acontece que agora ele não está mais presente enquanto tal. Trata-se de "não tocar o seu corpo, mas de tocar à sua eternidade, de não entrar em contato com a sua presença manifesta, mas de aceder à sua presença real, que consiste na sua partida." ${ }^{47}$

Em grego, o verbo haptein ("tocar") pode significar também "reter, parar", daí a seguinte versão, adotada por várias traduções da Bíblia, como a Revised Standard Version e a Biblia de Jerusalém: “Não me retenhas, pois ainda não subi ao Pai". Tocar ou reter o Cristo seria aderir à sua presença imediata e perder de vista a sua partida, pela qual o seu toque e a sua presença vêm a nós. A "ressurreição" não é outra coisa senão a partida. "'Ressurreição"' é levantada (surreição), aparecimento repentino do indisponível, do "desaparecendo" no próprio corpo e enquanto corpo." 48 O corpo morto permanece morto, é o que produz o "vazio" do túmulo, mas o corpo que a teologia chamará mais tarde de "glorioso" revela que esse vazio é realmente o esvaziamento da presença. Essa "insurreição" de Jesus é uma glória que se dedica a decepcionar Maria e a afastar a sua mão estendida, pois o seu brilho não é outra coisa senão o vazio do túmulo. O "ressuscitado" expõe a brecha que não se ousa tocar, já que é só essa fenda que nos toca vitalmente: no ponto da morte. "O túmulo vazio i-limita a morte na partida do morto. Ele não está morto uma vez por todas, ele morre indefinidamente." 49 Aquele que diz "Não me toque" nunca cessa de partir, pois a sua presença é a do desaparecimento, indefinidamente renovado ou prolongado. O que Jesus diz é que ele é só partida, que o seu ser e sua palavra se resumem nisso: "Eu, a verdade, estou partindo".

${ }^{47}$ NANCY, Jean-Luc. Noli me tangere. Op. cit., p. 15.

${ }^{48}$ NANCY, Jean-Luc. Noli me tangere. Op. cit., p.15.

${ }^{49}$ NANCY, Jean-Luc. Noli me tangere. Op. cit., p. 16. 
Enfim, quando Jesus diz que está indo "ao Pai", isso significa que está partindo, absolutamente: o "pai" não é senão o ausente e o afastado, exatamente o oposto de "meus irmãos", aos quais a mulher é enviada. Ele está se ausentando, rumo à dimensão de onde vem a glória, isto é, o brilho do que é mais do que presença, do que está em excesso em relação ao dado e ao disponível. Essa glória não é vista, pois só brilha à medida em que é recebida e transmitida. Assim como diz o apóstolo: "E nós todos que, com a face descoberta, refletimos como num espelho a glória do Senhor, somos transfigurados nessa mesma imagem, cada vez mais resplandecente (de glória em glória), pela ação do Senhor, que é Espírito (2 Cor 3, 18)".

A ressurreição não é a volta à vida. É a glória no coração da morte, uma glória sombria, que marca a descontinuidade de outra vida em e da morte. A ressurreição não é um processo de regeneração, mas é a relação de fé com aquele que diz: "Eu sou a ressurreição" (Jo 11, 25). Trata-se de se manter firmemente numa atitude decidida frente à morte, uma atitude que é literalmente anastasis ou ressurreição, isto é, o levantamento ou a elevação como verticalidade perpendicular à horizontalidade do túmulo, sem deixá-lo, mas o reafirmando na posição de um intocável, de um inacessível. É a verdade de toda vida enquanto mortal e singular. Não há comum medida com a ordem horizontal, na qual a vida morta se reduz a restos materiais, nem com qualquer representação da passagem para uma outra vida no reino das sombras. Anastasis vem ao sujeito a partir do outro no seio do próprio sujeito. É o outro que se levanta e ressuscita dentro do próprio morto. É o outro que ressuscita para mim, mais do que ele me ressuscita. A ressurreição não é uma ação que eu teria realizada, mas, antes, uma passividade à qual estou submetido ou que eu recebo, a mesma passividade e a mesma paixão presentes na morte. Não é nem morte nem vida, é simplesmente um presente. E é sempre a apresentação de uma partida.

\subsection{Mè mou haptou - Noli me tangere}

No trecho de Jo 20,13-18, Maria quer ver Jesus. Ele se deixa ver por ela porque os olhos dela procuraram enxergar dentro do túmulo e souberam enxergar na noite do invisível. Nancy traduz o Noli me tangere do modo seguinte: "Você vê, mas essa visão não é e não pode ser um toque, se o próprio toque procura figurar a imediaticidade de uma presença; você vê o que não está presente e você toca o intocável que se mantém fora do alcance de suas mãos, precisamente como se aquele que você vê na sua frente tivesse já deixado o lugar do encontro."

Na pintura, contrariamente às representações da ressurreição propriamente dita (como em Grünewald ou Piero della Francesca), as cenas das aparições do ressuscitado são mais discretas e apresentam uma aparência de "natura- 
lidade". Jesus convida os discípulos a superarem a impressão de ver um fantasma e a tocá-lo para verificar que ele está presente corporalmente. Ao contrário da crença, a fé vê e escuta lá onde não há nada de extraordinário a ser visto e ouvido. Ela sabe ver e ouvir sem tocar. É o caso também dos episódios de Tomé e de Emaús. Essas cenas nos convidam a compreender o que nenhuma representação pode sustentar, isto é, que nenhuma presença apresenta aquele que se distancia, quando a verdade da presença se ausenta.

Os pintores souberam reconhecer uma intriga delicada que toma forma entre o visível e o invisível, cada um chamando e rejeitando o outro, cada um tocando no outro e o distanciando de si mesmo. Rembrandt, por exemplo, captura a intriga com a maior clareza. O túmulo está no ponto mais alto do jardim, enquanto a abertura escura da cova fica a nossa frente do lado direito, no mesmo nível que a luz poderosa do nascer do sol do lado esquerdo, cuja brancura dourada absorve a roupa de Jesus (ao passo que o manto de Maria parece afundar nas sombras e se prolongar num lençol - talvez a mortalha vazia). O conjunto da tela parece compor um rosto, com um olho escuro e o outro claro. Entre os dois olhos, a linha divisória da sombra e da luz, na parede da rocha na qual o túmulo foi cavado, divide o rosto de Maria em duas partes iguais, captando o momento em que ela se volta para Jesus, e o descobre sem reconhecê-lo. Seus olhos se dirigem para ele enquanto ele olha para ela.

Rembrandt situa a cena instantes antes do Noli me tangere, indicando, contudo, sutilmente o motivo do toque. Mas nesse primeiro momento, é o impossível contato do dia e da noite que ocupa o pintor: a sua tangên$\mathrm{cia}^{50}$ sem contato, sua comunidade sem mistura, sua proximidade sem intimidade. O ressuscitado não está vindo do túmulo, mas do lado da luz, assim como o dia não vem da noite, mas a confronta, sem dissipar a profunda escuridão da caverna. O mistério da ressurreição não é evocado por alguma glorificação de carne reconstituída, mas é iluminado lá onde está escondido, "num ponto de tangência afastado atraso da tela, como se fosse no silêncio do texto, onde luz e sombra interagem sem se tocar, onde elas se dividem, cada uma empurrando a outra - onde uma é a verdade da outra, sem mediação e sem conversão de uma na outra." ${ }^{51}$

\footnotetext{
${ }^{50}$ Tangentes são curvas que se tocam num ponto ínfimo, isto é, quase não se tocam. Ao comentar o quadro de Pontormo que representa a "Visitação", Nancy chama a atenção para o quase-contato, a tangência dos ventres grávidos de Maria e Elizabete: "A atenção se volta para os ventres grávidos entre os quais sopra o espírito, que se tocam sem se tocar, num ponto ínfimo como uma tangência, uma passagem ao limite". Ver: NANCY, Jean-Luc. Visitation. De la peinture chrétienne. Paris: Galilée, 2001, p. 15. A tangência é também o modo como Derrida caracteriza o pensamento de Jean-Luc Nancy sobre o tocar do corpo.

${ }^{51}$ NANCY, Jean-Luc. Noli me tangere. Op. cit., p.26.
} 


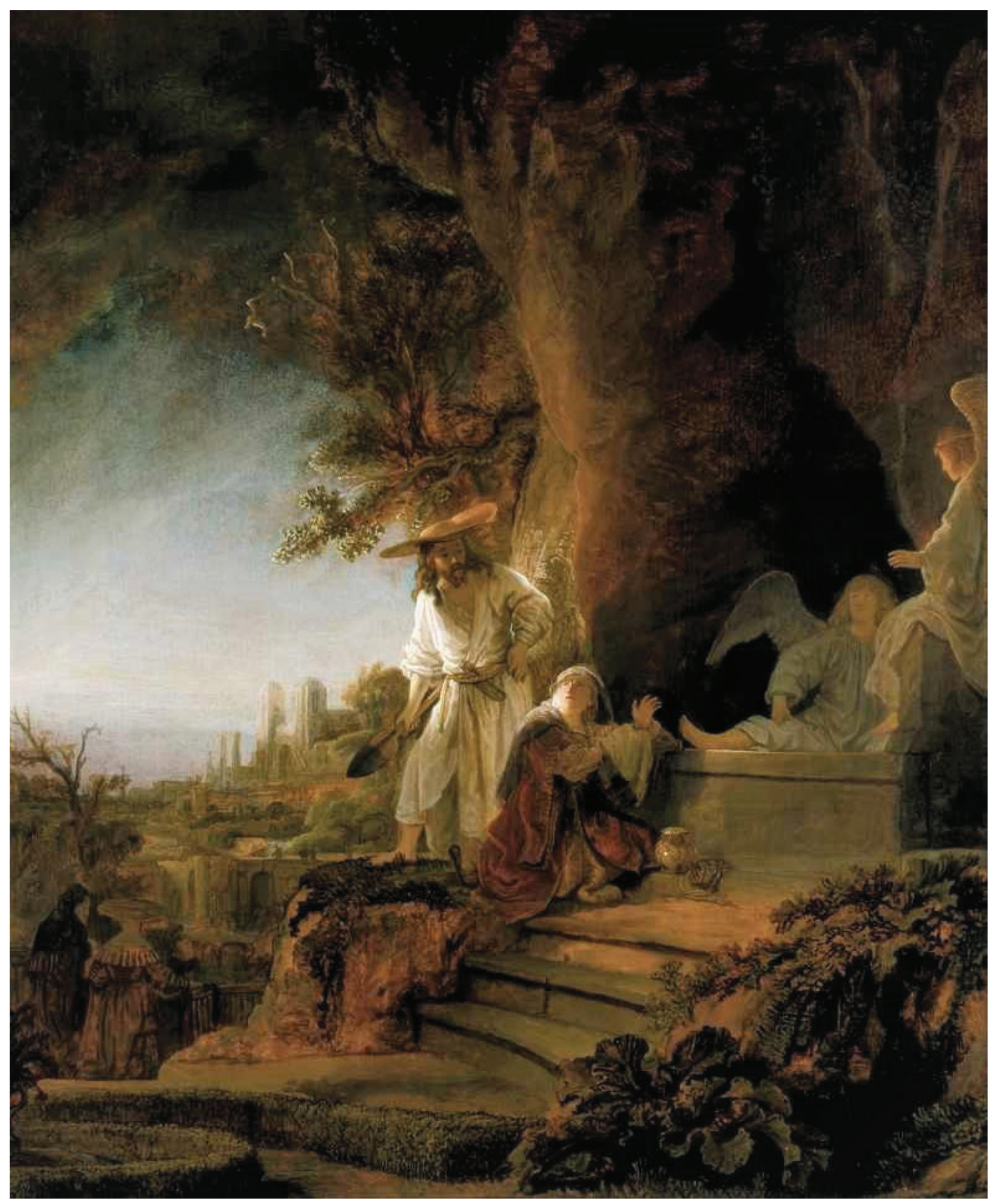

Rembrandt van Rijn: Cristo e Maria Madalena no túmulo.

https://santhatela.com.br/rembrandt/rembrandt-cristo-e-maria-madalena-no-tumulo-1638antathela.com.br

Acesso em 31/10/2020. 
A dificuldade de reconhecimento de Jesus aparece em vários relatos das aparições do ressuscitado. O seu significado é duplo. De um lado, há uma espécie de suspensão da semelhança de Jesus consigo mesmo. Ele é o mesmo sem ser o mesmo, como todo morto aparece. É o aparecimento de um aparecido e desaparecido. "A partida está inscrita na presença, a presença apresenta o próprio esvaziamento. Ele já partiu, ele não está mais onde está, ele não é mais como ele é: ele está morto." 52 Por outro lado, o reconhecimento difícil e incerto indica a natureza da fé. Esta não consiste em reconhecer o conhecido, mas em confiar no desconhecido. Maria estava vendo sem enxergar. A voz de Jesus faz Maria se voltar para trás, e ela o reconhece quando ele a chama pelo nome. Ela acredita porque ouve, e responde à voz daquele que mantem a mesma aparência: a aparência do jardineiro. "De fato, Maria vê o jardineiro, um homem comum procurando outro homem comum falecido, cujo túmulo aberto expõe a ausência incomensurável." ${ }^{53}$ Como Abraão, Maria ouve o que está endereçado a ela e a nenhum outro, pelo próprio nome. Nada é dado ou revelado, ela recebe apenas a incumbência de repetir que Jesus partiu. Como Abraão, Maria demonstra a sua fé apenas pela sua partida.

Ao colocar o acento no tato, no toque, a tradução latina e traduções modernas remetem às mãos da personagem. Toca-se com a mão e toca-se primeiro a mão. Nas representações picturais do Noli me tangere, há uma grande variedade no movimento das mãos, mas se trata sempre de uma promessa ou de um desejo de segurar, ou de reter o outro, ou ainda de juntar as mãos. As mãos são um elemento decisivo da composição, bem no seu centro. Na cena analisada, tudo começa e termina com as mãos, pois são signos da chegada de Maria e da partida de Jesus. São mãos a ponto de se juntarem, mas ainda separadas e distantes, como a sombra e a luz, mãos que trocam saudações misturadas com desejos, que mostram corpos, mas que apontam também para o céu. As mãos de Maria Madalena se voltam para Jesus numa postura de demanda, elas tentam tocá-lo ou saudar a sua presença, na borda do seu corpo ou da sua roupa. Ao contrário, é difícil saber se as mãos de Jesus se dirigem para a mulher para abençoá-la ou para mantê-la à distância. Com certeza, ele não quer segurá-la, nem tomar a mão dela na sua. Ele só quer enviá-la anunciar as notícias. Como ele, ela precisa partir. Ela é a primeira mensageira da novidade. Muitas vezes na pintura, as mãos do Cristo apontam para duas direções: uma para o céu e a outra para Maria, em vista de pará-la e mandá-la de volta para a sua missão.

O gesto de Jesus pode significar: "Não me toque, pois sou eu quem toca você". Há sempre uma combinação muito singular de distanciamento e

${ }^{52}$ NANCY, Jean-Luc. Noli me tangere. Op. cit., p. 28.

${ }^{53}$ NANCY, Jean-Luc. Noli me tangere. Op. cit., p.30. 
ternura, benção e carícia. "Não me toque, pois estou te tocando, e esse toque quer mantê-la à distância" ${ }^{54}$. Amor e verdade tocam ao afastar: eles forçam o afastamento daqueles que alcançam, pois revelam, pelo próprio toque, que estão fora de alcance. É ao serem inatingíveis que eles nos tocam. Noli me tangere não significa simplesmente "Não me toque", mas "Nem queira me tocar", "nem pense em me tocar", pois o verbo nolo é o negativo de volo. Desse modo, o latim desloca o sentido do verbo grego haptein. "Não o faça, mas se você já o fez, esqueça isso logo". "Você não segura nada; você é incapaz de segurar ou reter qualquer coisa, e é precisamente o que você deve amar e conhecer. [...] Ama o que escapa de você. Ama aquele que vai. Ama o fato de ele ir." ${ }^{55}$

"A ressurreição não é uma ressuscitação: é a extensão infinita da morte que desloca e desfaz todos os significados de presença e ausência, animado e inanimado, corpo e alma. A ressurreição é a extensão de um corpo na medida do mundo e do espaço no qual todos os corpos estão lado a lado." 56

O cuidado do jardineiro não constitui um culto, mas uma cultura. Toda cultura humana mantém a relação com a morte, sem a qual não haveria nenhuma relação, mas uma aglutinação de tudo. "Sem morte, só haveria contato, contiguidade, contágio, uma propagação cancerosa da vida que já não seria mais vida, ou que seria apenas vida e não existência, uma vida que não seria mais anastasis, ao mesmo tempo." ${ }^{57} \mathrm{~A}$ morte abre a relação, isto é, o compartilhamento da partida. Cada um está incessantemente vindo e indo. A revelação não revela nada, acima de tudo não revela a transfiguração do morto num vivo (o episódio da transfiguração antecipa a glória do Cristo morto; ele mostra que ninguém pode se estabelecer na glória: só podemos ser expostos fugazmente ao seu brilho; fugazmente entre vida e morte, ou entre o toque e a retração).

A revelação - da qual a ressurreição seria o ápice e a última palavra - revela que não há nada a mostrar, a fazer aparecer fora do túmulo, nenhuma aparição, nenhuma teofania ou epifania de glória celeste. Não há mais uma última palavra, nem mesmo um adeus ou um salve entre Jesus e Maria Madalena.

O corpo glorioso é o corpo que vai embora enquanto fala, que só fala ao ir embora, que se afasta tanto na escuridão do túmulo quanto na aparência comum do jardineiro. Sua glória só irradia para os olhos que

\footnotetext{
${ }^{54}$ NANCY, Jean-Luc. Noli me tangere. Op. cit., p. 36

${ }^{55}$ NANCY, Jean-Luc. Noli me tangere. Op. cit., p.37.

${ }^{56}$ NANCY, Jean-Luc. Noli me tangere. Op. cit., p. 44.

${ }^{57}$ NANCY, Jean-Luc. Noli me tangere. Op. cit., p. 45.
} 
sabem como ver, e esses olhos só veem o jardineiro. $\mathrm{O}$ falar do nome diz que ambos morrem e não morrem. O nome vai e fica ao mesmo tempo, pois carrega a revelação da finitude infinita de cada um. "Maria" revela Maria a si mesma, revelando ao mesmo tempo a partida da voz que chama e a missão ligada ao seu nome: ir embora e anunciar a partida. A ressurreição designa o singular da existência enquanto o nome, designa o nome como nome do morto. Ser chamado pelo nome é estar no ponto da partida e deixar o sentido na sua borda, uma borda que, na verdade, nem foi alcançada.

Não tocar, não deter, não aderir, não pensar em familiaridade ou segurança. Não crer, de modo algum. Permanecer firme nessa descrença. Permanecer fiel ao que fica na minha partida: o seu nome. "No seu nome, não há nada a ser apreendido ou apropriado, apenas o fato que ele te foi endereçado, a partir do imemorial e em vista do inalcançável, a partir do fundo sem fundo que está sempre em processo de partida". É a palavra que Jesus dirige a Maria Madalena.

A revelação não é a aparição repentina de uma glória celestial. Ao contrário, ela consiste na partida do corpo elevado à glória. É ao se ausentar, ao se tornar ausente, que o corpo revela, mas não é aquele que se afasta que revela; é aquela que recebeu a incumbência de ir anunciar a partida dele. Afinal, é o corpo carnal que revela o corpo glorioso, e é por isso que os pintores souberam pintar o corpo sensual de Maria Madalena, até quando ela estava perto da morte no seu retiro de penitente. "Noli me tangere é a palavra e o instante da relação e da revelação entre dois corpos, isto é, de um único corpo infinitamente alterado e exposto ao mesmo tempo na sua queda e na sua 'surreição'." 58 Por que um corpo? Porque só um corpo pode ser rebaixado ou elevado, porque só um corpo pode tocar ou não tocar. Um espírito não pode fazer nada disso. Um corpo abre a sua presença ou afasta a presença de si mesmo e assim traz outros juntos com ele: Maria Madalena se torna o corpo verdadeiro daquele que partiu.

O toque se afasta do objeto que ele toca, no momento preciso em que ele é tocado por ele. Sem esse afastamento, o toque não seria mais o que é, nem faria o que faz. Ele seria reificado, aglutinado com a coisa. "Haveria identificação, fixação, propriedade, imobilidade." ${ }^{59}$ Um toque verdadeiro é um toque contido, não apropriador nem identificador: "Me afague sem me tocar!". Jesus não proíbe isso a Maria Madalena. Ele não se deixa agarrar, mas permite o toque de uma presença e, em consequência, o eclipse, a ausência, e a partida na qual a presença deve

${ }^{58}$ NANCY, Jean-Luc. Noli me tangere. Op. cit., p. 48.

${ }^{59}$ NANCY, Jean-Luc. Noli me tangere. Op. cit., p. 50. 
sempre se dar a fim de se apresentar a si mesma. Não é isso que faz toda carícia e todo beijo, um dom de si mesmo que toca e se retrai, convidando para um reencontro num outro momento ou em outro lugar?

\subsection{Maria de Magdala}

Não é sem motivo que Maria de Magdala, que chamamos de "Maria Madalena", recebeu a tarefa de anunciar o que viu e o que pensa ter visto. A história dela durante a vida de Jesus prefigura a sua presença frente ao túmulo dele. Vale ressaltar que Nancy segue a tradição, à medida que esta opera uma fusão entre várias figuras do Evangelho. Aqui, ele assimila a mulher do Noli, também presente ao pé da cruz à Maria, irmã de Marta e Lázaro, presente na ressurreição do irmão e que, numa outra ocasião, derrama um perfume valioso nos pés de Jesus e os unge com seus cabelos. Assim, Maria Madalena esteve sempre numa grande proximidade com a morte em geral e em particular com a morte de Jesus. No episódio da morte e ressurreição de Lázaro, Maria manifestou sua fé em Jesus ao dizer: "Senhor, se estivesses aqui, o meu irmão não teria morrido". Na presença de Jesus, a morte não pode ser reduzida à cessação da vida: ela se torna vida até na iminência incessante do "ausentamento". No episódio da unção de Betânia, Jesus responde à crítica de Judas: "Deixa-a, que ela o (o meu corpo) conserve para o dia da minha sepultura! Pois sempre tereis pobres convosco; mas a mim nem sempre tereis" (Jo 12, 7-8). É a mesma Maria que "escolheu a melhor parte" (Lc $10,38-42)$, ao ficar sentada aos pés de Jesus, ouvindo suas palavras. Ela escolheu a parte que não pertence a esse mundo. Num texto paralelo, é a mulher de má fama que, no Evangelho de Lucas $(7,36-49)$, tocou os pés de Jesus e os cobriu de lágrimas, de beijos e de perfume.

O sentido do episódio é que a "vida boa" não é uma vida conforme à moral correta, mas aquela que, neste mundo, se mantém na maior proximidade com o que não é deste mundo: a exterioridade do mundo que é o vazio do túmulo e o vazio de deus, o vazio aberto dentro do deus ou enquanto "Deus", pelo nascimento do homem ao mundo, pelo nascimento do mundo ao mundo. ${ }^{60}$

É Maria Madalena que tocou mais visivelmente em Jesus (fisicamente e espiritualmente). Sua unção teria embalsamado o corpo de Jesus com antecedência, antecipando sua morte e sua ressurreição, antecipando o seu corpo glorioso, ao lhe conferir em vida a glória insensata de ser perfumado por uma mulher amorosa. No quadro de Rembrandt, o vaso ao lado de Maria lembra o episódio da unção. A mão de Maria parece

${ }^{60}$ NANCY, Jean-Luc. Noli me tangere. Op. cit., p. 39. 
lavar e untar o pé do anjo, estendido para fora do túmulo. É como se Jesus dissesse, lembrando a unção: “Não me toque, pois você já me tocou e guardei o seu perfume sobre mim, do mesmo modo que ele me guarda na morte e olha para essa verdade insensata do túmulo. Não me toque, já foi feito. O seu precioso perfume já foi derramado; deixe-me ir. E, por sua vez, você também: vá e anuncie que estou indo". ${ }^{61}$

Por outro lado, o corpo de Jesus não teria apodrecido, porque o perfume de Maria Madalena lhe deu o "odor de santidade" por antecipação, o que é outro aspecto do corpo glorioso. O homem louco de Nietzsche fala no fedor da decomposição de Deus. Sem dúvida nenhuma, para Nancy, Deus continua morto, mas a morte de Jesus se distingue dessa putrefação divina, tanto no seu princípio quanto no seu incessante movimento de desconstrução. "A morte de Jesus fala de outra morte e outra vida, de uma anastasis ou glória que constituiria algo como o aroma - a sensibilidade, a sensualidade - da morte insensível e irreparável, que constituiria sua 'divindade' enquanto sua 'feminilidade', isto é, para retomar esta palavra, sua 'santidade'." ${ }^{62}$ Maria Madalena vê vida na morte porque viu a morte na vida. Maria Madalena, que foi tantas vezes representada como penitente no deserto ao lado de uma caveira, com os cabelos soltos e sem véu - são signos tanto da sua vida amorosa quanto do seu gesto aos pés de Jesus - reúne graça e sensualidade, carícia e reverência como vida e morte, como homem e mulher, como leveza e gravidade, como aqui e lá, sem mesclar os polos, mas os compartilhando por um toque que, por si mesmo, se distancia e se difere a si mesmo. De certo modo, ela é a santa por excelência, porque ela se mantém no ponto onde o toque do sentido é idêntico à sua retração. É o ponto do abandono: ela desiste de si mesma a favor de uma presença que é apenas uma partida, de uma glória que é apenas escuridão. $\mathrm{O}$ seu abandono deriva tanto do amor quanto do desânimo, sem que um deles alivie, restaure ou substitua o outro. Antes, a simultaneidade de ambos constitui a elevação (levée) deste momento, um levantamento que desaparece no mesmo momento em que emerge.

\section{Considerações finais}

A reflexão de Jean-Luc Nancy sobre a desconstrução da encarnação e da ressurreição como figuras centrais na desconstrução do próprio cristianismo está embasada numa fenomenologia do corpo, no qual o tato ocupa uma posição privilegiada. $\mathrm{O}$ toque é sempre, ao mesmo tempo,

${ }^{61}$ NANCY, Jean-Luc. Noli me tangere. Op. cit., p. 41.

${ }^{62}$ NANCY, Jean-Luc. Noli me tangere. Op. Cit., p. 41. 
um movimento de aproximação e de retração do corpo, de presença e de ausência.

Depois que o corpo de Deus se tornou o corpo do homem e se ausentou, os corpos são a exposição de Deus (a sua expeausition) na pele como lugar do toque e do distanciamento. Apenas sobraram os lugares divinos, doravante ocupados pelo mundo dos nossos corpos. O corpo é uma imagem que não representa, é a vinda à presença sempre em ação, até na morte. $\mathrm{O}$ corpo, que se identifica com o pensamento, é sempre também limite, espaço aberto, extensão e exterioridade da presença-ao-mundo, isto é, existência sem essência, na sua singularidade. Os corpos estão sempre em partida - na morte permanente - carregando e deixando, de uma vez, o seu espaçamento, que é a sua exposição no ser, o lugar onde constantemente se tocam e se afastam. Todo corpo, inclusive o meu, é sempre alteridade radical. O sentido se dá no distanciamento do tato, não na interioridade. Os corpos pesam sobre e contra os outros. Eles se glorificam na extensão e se destroem na concentração. $\mathrm{O}$ ser-estendido é o lugar do sentido, da diferenciação e da comunidade do mundo. Todo corpo está em simbiose com o exterior, que é apenas a contiguidade dos corpos. É a pele que anima o corpo e o dirige ao mundo e a ele mesmo. Ela representa a conjunção do espírito e do corpo.

Ao falar em encarnação, Nancy apresenta em primeiro lugar o conteúdo da fé cristã. $O$ verbo não precisou penetrar numa carne antes dada fora dele: o próprio verbo tornou-se a carne. A encarnação não é a morada provisória do deus na carne, é o "verbo feito carne", ou a própria carne como sentido. Assim, o corpo é o evento do espírito, isto é, o espírito não se mantém fora do mundo, mas abre-se no meio dele. $\mathrm{O}$ "deus" se fez "corpo" ao esvaziar-se de si mesmo (kénosis), de modo que a ausência ou o vazio-de-divindade seja a sua verdade mais profunda. Assim começa a desconstrução, no apagamento de Deus no homem que é o sentido do mundo. Mas a desconstrução precisa se aprofundar como superação do corpo como signo do sentido enquanto interioridade, além de toda significação e representação. O espírito do cristianismo está no corpo como mistério revelado, como Deus retirado na carne. Mas ele se desfaz no amontoado das vítimas, dos corpos identificados com suas chagas no nosso mundo, à medida que se mundializa. A esperança de resiliência está na "ecotecnia", que produz a interconexão de todos os corpos.

Por sua vez, a ressurreição desconstruída não visa a atravessar a morte, mas, ao mergulhar nela sem volta, a ressuscitar a própria morte. A ressurreição não é uma segunda vida, mas é o endireitamento pelo qual o curso horizontal de uma vida gira em sentido vertical. Na morte ressuscitada, na qual me ausento de mim mesmo e do sentido, não me exponho apenas à verdade, mas sou eu mesmo a verdade em ato. A ressurreição é consen- 
timento, paciência da passividade. A única consolação da desolação é o "salve" dirigido ao morto chamado pelo nome. O "salve" dá ao mundo abismado do morto a sua dignidade de mundo. A fé nunca consiste numa crença na felicidade futura. Ela é saudação (salut) ou endereçamento ao outro do mundo, pois "Deus" não designa senão esta alteridade na qual a alteração do mundo, de todo o mundo, se faz absoluta, sem recurso possível.

O texto intitulado Noli me tangere é uma aplicação narrativa e visual do sentido do corpo sensível ao toque, que está no centro da compreensão da encarnação e da ressurreição no seu processo interminável de desconstrução e reconstrução. Para a revelação, a imagem - a parábola - é idêntica ao original, o que implica a identidade do invisível e do visível. Nancy reconhece a desconstrução, já no próprio texto evangélico, de todo caráter religioso ou sagrado, da ressurreição como partida na morte. Por um lado, o cristianismo inventou a religião do toque, pois Jesus sempre se deixou tocar, inclusive nos relatos das aparições depois da ressurreição. A única exceção, presente no nosso texto, visa a ressaltar o significado da partida, que é a ressurreição. Tocar ou reter o Cristo seria aderir à sua presença imediata e perder de vista a sua partida, pela qual o seu toque e a sua presença vêm a nós. Pois, o morto não está morto uma vez por todas, ele morre indefinidamente. A ressurreição não é a volta à vida, é a glória no coração da morte. Ao contrário da crença, a fé vê e escuta lá onde não há nada de extraordinário a ser visto e ouvido. Ela sabe ver e ouvir sem tocar.

Na pintura, o mistério da ressurreição não é evocado por alguma glorificação de carne reconstituída, mas é iluminado lá onde está escondido, num ponto de tangência sem contato, de comunidade sem mistura, de proximidade sem intimidade. A presença de Jesus é o aparecimento de um aparecido e desaparecido, ou, melhor, desaparecendo. De novo, a convocação pelo próprio nome é decisiva. É o que designa a partida e a missão de anunciar a partida. São decisivas também as mãos, pelas quais os corpos, de uma vez, se tocam e não se tocam. Aqui se manifesta todo o esplendor e toda a ambiguidade do amor dos seres humanos, isto é, dos corpos. Não há mais nada a mostrar, não há mais uma última palavra, nem mesmo um adeus ou um salve entre Jesus e Maria Madalena. Podemos entender isso um pouco melhor, depois de nove meses de pandemia, sem poder se tocar nem se abraçar. Mas é impossível não pensar aqui nos mortos, enterrados sem abraço e sem toque, sem luto e sem velório, quase que clandestinamente, na exacerbação do abandono, e que o corpo de Cristo reerguido na morte continuará evocando até o fim sem fim da sua desconstrução. Será que poderemos nos manter firmes na fé, desistindo uma vez por todas, de toda crença e de todo fantasma? Possamos sempre nos saudar uns aos outros na vida e na morte! 
Qual será o futuro do cristianismo? No processo da desconstrução, iniciado pelo próprio cristianismo, e no qual ele continua o mesmo sem ser totalmente o mesmo,

há uma transformação do cristianismo que vai sempre para além de seus dogmas, de suas crenças e instituições. É na direção da dignidade do "aberto", logo, do futuro, que as expressões "desconstrução" e "declosão" do cristianismo encontram sua significação plena, no momento preciso em que este último perde sua soberania de sentido e se expõe a uma responsabilidade que o excede. ${ }^{63}$

\section{Para Jean-Luc Nancy,}

a palavra "declosão" é um modo de indicar dois movimentos simultâneos, de um lado, o movimento pelo qual a construção em geral se desconstrói a si mesma, do outro lado, aquele pelo qual se abre um espaço, do qual já podemos saber, que ele está além do Ocidente e de todas as suas propostas e disposições - já, mas sem que nada nos permita de designar, menos ainda de desenhar esse espaço. [...] Estamos exatamente no ponto de declosão: isto se abre, isto se abre sobre nada, porque só constitui uma exterioridade por e em a própria abertura. ${ }^{64}$

Para Jacques Derrida, o projeto de "descristianização o mundo" ou "desconstrução do

Cristianismo é, na sua essência, tão necessário quanto impossível. Na realidade, não se trata de um projeto, mas de um fato, um evento em obra há dois mil anos, que não pode ser desejado nem produzido. $\mathrm{O}$ cristianismo não é desconstrutível porque ele é apenas a sua própria desconstrução, do mesmo modo que a desconstrução é um procedimento essencialmente cristão. ${ }^{65}$

Jean-Luc Nancy saúda a fé como a atitude de estar-já-no-aberto, quando o exterior já irrompe. Essa fé não tem nada a ver com uma espécie de convicção adquirida por reflexão ou meditação, por argumentação ou advertência a respeito de quaisquer motivos. Não é nenhum cálculo a respeito de um céu de recompensa ou de vida eterna, mas é a eternidade já "reencontrada", conforme a palavra de Rimbaud.

\footnotetext{
${ }^{63}$ COHEN-LÉVINAS, Danielle. Requiem pour le catholicisme ? Un reste de christianisme. Entretien avec Jean-Luc Nancy. In : Revue des deux mondes, s.d., p. 1.

${ }^{64}$ COHEN-LÉVINAS, Danielle. Requiem pour le catholicisme ? Un reste de christianisme. Op. cit., p. 4. ${ }^{65}$ ESPOSITO, Roberto. Chair et corps dans la déconstruction du christianisme. In : GUIBAL, Francis e MARTIN, Jean-Clet (Dir.). Sens en tous sens. Autour des travaux de Jean-Luc Nancy. Paris : Galilée, 2004, p.156-157.
} 


\section{Referências bibliográficas}

ANTONIOLI, Manola. O tocar - Jacques Derrida e Jean-Luc Nancy. In: EYBEN, Piero (Org.). Pensamento intruso. Jean-Luc Nancy \& Jacques Derrida. Vinhedo, SP : Horizonte, 2014, p. 29-40.

COHEN-LÉVINAS, Danielle. Requiem pour le catholicisme ? Un reste de christianisme. Entretien avec Jean-Luc Nancy. In : Revue des deux mondes, s.d., p. 1-13. www.revuedesdeuxmondes.fr/wp-content/uploads/2016/11/c8965650b0df6342360517edb9b5f717.pdf. Acesso em 19/02/2019.

DERRIDA, Jacques. Le toucher, Jean-Luc Nancy. Paris : Galilée, 2000.

ESPOSITO, Roberto. Chair et corps dans la déconstruction du christianisme. In : GUIBAL, Francis e MARTIN, Jean-Clet (Dir.). Sens en tous sens. Autour des travaux de Jean-Luc Nancy. Paris : Galilée, 2004, p. 153-174.

EYBEN, Piero (Org.). Pensamento intruso. Jean-Luc Nancy \& Jacques Derrida. Vinhedo, SP : Horizonte, 2014.

HIGUET, Etienne Alfred. A fé na filosofia pós-moderna: Jacques Derrida e Jean-Luc Nancy. Correlatio. Universidade Metodista de São Paulo, vol. 12, no 24, 2013, p. 29-48.

HIGUET, Etienne Alfred. O projeto de desconstrução do cristianismo de Jean-Luc Nancy. Horizonte. PUCMG, Belo Horizonte, 2016a, vol. 14, p. 518-542.

HIGUET, Etienne Alfred. A espiritualidade da adoração (Ad-oratio): reflexão a partir de Jean-Luc Nancy. Revista Brasileira de Filosofia da Religião. ABFR, Brasília, 2016b, vol. 3, no 1, p. 92-111.

HIGUET, Etienne Alfred. Vida e Encarnação no ser humano, em Cristo e na pintura de Kandinsky. Leitura de Michel Henry. Estudos de Religião, v. 34, n.2, maio-ago. 2020,

p. 41-69.

HIGUET, Etienne Alfred. Leitura filosófica da pintura cristã. In: CALVANI, Carlos E. B.; BEZERRA, Cícero C. (Org.). Religião: linguagens. Curitiba: Editora CRV, 2020, p. 177-192.

NANCY, Jean-Luc. Visitation. De la peinture chrétienne. Paris: Galilée, 2001.

NANCY, Jean-Luc. L'adoration (Déconstruction du christianisme II). Paris: Galilée, 2010

NANCY, Jean-Luc. La déclosion (Déconstruction du christianisme I). Paris: Galilée, 2005.

NANCY, Jean-Luc. A adoração (Desconstrução do Cristianismo, 2). Coimbra: Terra Ocre/Palimage, 2014.

NANCY, Jean-Luc. A declosão (Desconstrução do Cristianismo, 1). Coimbra: Terra Ocre/Palimage, 2016.

NANCY, Jean-Luc. Des lieux divins, suivi de Calcul du poète. 2. ed. Mauvezin (França): T.E.R., 1997. 
NANCY, Jean-Luc. Corpus. Paris: Métaillé, 2000a.

NANCY, Jean-Luc. Noli me tangere. On the Raising of the Body. New York: Fordham University Press, 2008. Trad. de Noli me tangere. Essai sur la levée du corps. Paris: Bayard, 2003.

NANCY, Jean-Luc e LÈBRE, Jérôme. Signaux sensibles. Entretien à propos des arts. Paris: Bayard, 2017.

NANCY, Jean-Luc. Le sens du monde. Paris: Bayard, 1993.

NANCY, Jean-Luc. Les muses. Paris: Galilée, 1994.

NANCY, Jean-Luc. Être singulier pluriel. Paris: Galilée, 1996.

NANCY, Jean-Luc. L'intrus. Paris: Galilée, 2000b.

Endereço do Autor:

Rua Dona Ana Neri, 95

03106-010 São Paulo - SP

etienne.higuet@gmail.com 